\title{
National Early Warning Score 2: transcultural adaptation to Brazilian Portuguese
}

\author{
National Early Warning Score 2: adaptação transcultural para o português do Brasil \\ National Early Warning Score 2: adaptación transcultural para el portugués de Brasil
}

\author{
Ana Paula Amestoy de Oliveira ${ }^{a}$ \\ Janete de Souza Urbanetto ${ }^{b}$ \\ Rita Catalina Aquino Caregnato ${ }^{a}$
}

How to cite this article: Oliveira APA, Urbanetto JS, Caregnato RCA. National Early Warning Score 2: transcultural adaptation to Brazilian Portuguese. Rev Gaúcha Enferm. 2020;41:e20190424. doi: https://doi. org/10.1590/1983-1447.2020.20190424
Universidade Federal de Ciências da Saúde de Porto Alegre (UFCSPA), Programa de Pós-Graduação em Ensino na Saúde. Porto Alegre, Rio Grande do Sul, Brasil.

Pontifícia Universidade Católica do Rio Grande do Sul (PUCRS), Escola de Ciências da Saúde e da Vida, Programa de Pós-Graduação em Gerontologia Biomédica. Porto Alegre, Rio Grande do Sul, Brasil.

\section{ABSTRACT}

Objective: Cross-cultural adaptation of the National Early Warning Score 2 to Brazilian Portuguese.

Methods: A methodological study of a cross-cultural adaptation of a scale, based on the Beaton et al. framework, authorized by the Royal College of Physicians. Judges from nine Brazilian states, nurses and physicians evaluated the semantic, idiomatic, cultural, and conceptual equivalence between the original instrument and the translated versions. The nurses, working in inpatient or emergency units, conducted the pilot test, applying the final version to three case studies. Psychometric tests were used for data analysis: Content Validity Index (CVI), Kappa Coefficient, and Cronbach's Alpha.

Results: The adaptation showed a mean CVI of 0.98 and perfect/almost perfect inter-rater agreement, with scores above 0.80 . The consistency of the scale was 0.712 .

Conclusion: The process of cross-cultural adaptation of the scale to Brazilian Portuguese was successful, providing Brazilian professionals with an instrument aligned with patient safety.

Keywords: Clinical evolution. Clinical deterioration. Early Warning Systems. Translation. Patient safety.

\section{RESUMO}

Objetivo: Adaptar transculturalmente o National Early Warning Score 2 para o português do Brasil.

Método: Estudo metodológico de adaptação transcultural de escala, fundamentado no referencial de Beaton et al, autorizado pelo Royal College of Physicians. Juízes de nove estados brasileiros, enfermeiros e médicos, avaliaram equivalência semântica, idiomática, cultural e conceitual entre o instrumento original e as versões traduzidas. Enfermeiros, atuantes em unidades de internação ou emergência, realizaram o teste piloto, aplicando a versão final em três estudos de caso. Para análise de dados foram utilizados testes psicométricos: Índice de Validade de Conteúdo (IVC), Coeficiente de Kappa e Alpha de Cronbach.

Resultados: A adaptação apresentou IVC médio de 0,98 e concordância inter-avaliadores perfeito/quase perfeito, com pontuações superiores a 0,80. A consistência da escala foi igual a 0,712.

Conclusão: 0 processo de adaptação transcultural da escala para o português do Brasil foi exitoso, disponibilizando aos profissionais brasileiros um instrumento alinhado à seguranç̧a do paciente.

Palavras-chave: Evolução clínica. Deterioração clínica. Sistemas de alerta rápido. Tradução. Segurança do paciente.

\section{RESUMEN}

Objetivo: Adaptación transcultural del National Early Warning Score 2 al portugués de Brasil.

Métodos: Estudio metodológico de adaptación transcultural de escala, fundamentado en el referencial de Beaton et al, autorizado por el Royal College of Physicians. Jueces de nueve estados brasileños, enfermeros y médicos evaluaron la equivalencia semántica, idiomática, cultural y conceptual entre el instrumento original y las versiones traducidas. Los enfermeros, actuantes en unidades de ingreso o de emergencia, realizaron la prueba piloto, aplicando la versión final a tres estudios de caso. Para el análisis de datos se utilizaron pruebas psicométricas: Índice de Validez de Contenido (IVC), Coeficiente de Kappa, y Alpha de Cronbach.

Resultados: La adaptación presentó un IVC promedio de 0,98 y un acuerdo entre evaluadores perfecto/casi perfecto, con puntajes superiores a 0,80. La consistencia de la escala fue de 0,712.

Conclusión: El proceso de adaptación transcultural de la escala al portugués de Brasil fue exitoso, proporcionando a los profesionales brasileños un instrumento alineado con la seguridad del paciente.

Palabras clave: Evolución clínica. Deterioro clínico. Sistemas de alerta temprana. Traducción. Seguridad del paciente. 


\section{口INTRODUCTION}

The concept of Early Warning Scores - EWS was proposed by Morgan et al. in 1997, based on the alteration of vital signs as a risk alert for deterioration in the patient's health condition ${ }^{(1)}$. These scores are simple tools that assess physiological patterns and can be used at the bedside, assessing the risk of clinical deterioration and alerting as to the need for greater attention to the patient's health condition ${ }^{(1-2)}$.

Still pending additional co-related research studies, the EWS are often used by the Rapid Response Teams for patient assessment and early intervention, enabling more favorable outcomes and contributing to the patient safety process. In many countries, these teams are made up of health professionals who work actively, consolidated into the care routine of large hospitals, with positive responses to care ${ }^{(2-3)}$.

The National Early Warning Score (NEWS) was published in the English language by the Royal College of Physicians in the United Kingdom and, in December 2017, updated to the NEWS 2 version, aiming to standardize the assessment carried out in that country, which can be used upon admission, during hospitalization, and also in the pre-hospital period ${ }^{(4-5)}$. This scale is not recommended for assessing individuals under the age of 16 and pregnant women, and its score is calculated based on physiological parameters and on the use of supplemental oxygen ${ }^{(4-5)}$.

A number of studies have demonstrated the efficiency of the National Early Warning Score on many fronts: pre-hospital, emergency, discrimination of patients at risk for cardio-respiratory arrest, association with sepsis and septic shock, pre-admission to the Intensive Care Unit (ICU), and death ${ }^{(3,6-9)}$. All the studies describe the association between high NEWS scores and unfavorable outcomes related to clinical deterioration of patients, such as unscheduled transfer to the ICU or death ${ }^{(3,6-9)}$.

In the Brazilian health care practice, the occasional use of literally translated scores is observed, representing a fragility and a knowledge gap in this field. The process of cross-cultural adaptation of scales using specific methodologies such as the one proposed by Beaton ${ }^{(10)}$ demands time and rigor; however, it is characterized as a solution to this problem.

In this context, there is a direct relationship between the use of early warning scores and the strengthening of patient safety. Thus, the following research question was considered: "Can the National Early Warning Score 2 be adapted to Brazilian Portuguese?". As it is a scale that is easy to access and interpret, with the potential to corroborate the process of health care and patient safety, the objective of this study was to define the cross-cultural adaptation of NEWS 2 to Brazilian Portuguese.

\section{METHOD}

A methodological study for transcultural adaptation of scales ${ }^{(10)}$. The Royal College of Physicians (RCP), author of the scale, authorized the transcultural adaptation to Brazilian Portuguese before the start of the entire process.

NEWS 2 is composed of the following indicators: respiratory rate, oxygen saturation, temperature, systolic blood pressure, heart rate, consciousness and use of supplemental oxygen, and a specific assessment for patients with hypercapnic respiratory failure, such as Chronic Obstructive Pulmonary Disease (COPD) $)^{(4-5)}$. The final score is calculated by the values assigned to each of the items, with the total score varying from 0 (best prognosis) to 23 (worst prognosis).

The cross-cultural adaptation process was based on the methodology of Beaton et al. ${ }^{(10)}$, which is known and referenced for this type of study, and followed the following stages: 1) initial translation (English to Portuguese - T1 and T2); 2) summary of the translations (T12); 3 ) back-translation (Portuguese to English - B1 and B2); 4) evaluation of the semantic, idiomatic, conceptual, and cultural equivalences of each translated item by a committee of experts; 5) test of the pre-final version and, finally, feedback to the authors of the original version of the process ${ }^{(10)}$. It is highlighted that contact with the RCP was maintained throughout the transcultural adaptation process.

The first stage had two independent translations from English to Portuguese, by bilingual translators with Portuguese as their mother tongue. One of the translators was aware of the purpose of the study and had experience in the translation of documents related to the health field, while the other was not informed about the research objectives and, also, had no training or experience in the field. Each of the translators made comments about their doubts in the translation or their justifications for the final choice, generating two files: $\mathrm{T} 1$ and $\mathrm{T} 2^{(10)}$.

In the second stage, the summary of both translations was performed, generating a file called $\mathrm{T} 12$. For this summary, a discussion was carried out based on both versions, the one in Portuguese and the original version in English, by a group made up by both translators, the three researchers, and two neutral professionals, one nurse and one physician with clinical experience in intensive care/emergency.

With the summary, the third stage of the back-translation began, starting with version T12, from Portuguese to the instrument's original language, English. Two back-translations were performed, resulting in versions B1 and B2. Independent translators were hired, with English as their mother tongue and without knowledge of the concepts explored, in order 
to identify whether the Portuguese version reflected the original scale ${ }^{(10)}$.

In the fourth stage, the committee of experts was created. For this committee, physicians and nurses were selected, with recognized academic and assistance performance in Brazil. The researchers chose to search for the participants using the websites of public federal/state universities in Brazil, through the faculty working in disciplines related to adult health. In addition, referrals were requested from the Brazilian Association of Emergency Medicine (Associação Brasileira de Medicina de Emergência, ABRAMEDE), the Brazilian Society of Intensive Care (Associação de Medicina Intensiva Brasileira, AMIB) and the Brazilian Network of Nursing and Patient Safety (Rede Brasileira de Enfermagem e Segurança do Paciente, REBRAENSP) of reference professionals, being provided by these contacts.

As criteria for participating in the committee, the professionals should work in pre-hospital health services, emergency rooms, intensive care units and/or as teachers at universities, teaching courses in these areas, and accept the invitation. A total of 83 professionals were identified, covering all the Brazilian states, and invitations were sent to all via e-mail, with the effective return of 18 professionals. This stage aimed to evaluate the semantic, idiomatic, cultural, and conceptual equivalence between the original instrument and the translated versions ( $\mathrm{T} 1, \mathrm{~T} 2, \mathrm{~T} 12, \mathrm{~B} 1, \mathrm{~B} 2)$.

The evaluation of the summary version and its back-translation used a Likert-type scale ( $1=$ not equivalent, $2=$ impossible to evaluate equivalence without the item being reviewed, $3=$ equivalent, but requires minor changes, and $4=a b s o l u t e l y ~ e q u i v a l e n t)$, in which all the translated items were analyzed based on semantic equivalences (meaning of words), idiomatic (expressions and colloquialisms), cultural (experiences lived in the place to which the scale is translated), and conceptual (different meanings according to the demographic region) $)^{(10)}$. For all the items with scores of three (3) or less, the experts were asked to make considerations or to suggest changes ${ }^{(10-11)}$. With these equivalence analyses carried out by the expert committee, a new meeting was held, with the participation of the same group from the second stage, aiming to make the process of cross-cultural adaptation and adaptations of the pre-final version. At that moment, some questions of the experts committee, along with the translated material, were sent to the RCP for clarification and follow-up of the process.

With the pre-final version, the fifth stage began: a pilot test was applied, by means of three case studies made available by the RCP in training on the scale, in September 2018. These were applied to nurses who worked in inpatient units and in the emergency department of a university hospital in southern Brazil, constituting the target population for the final application of the instrument. According to the authors of the method, the ideal sample for this stage should contain between 30 and 40 participants ${ }^{(10)}$. This sample comprised a total of 35 nurses. The case studies were about fictional patients, addressing common pathologies in Brazilian hospitals, namely: COPD, community-acquired pneumonia, and urinary tract infection. Data related to the use of oxygen supplementation devices were also provided, as well as vital sign measures. The nurses should apply the scale based on the information provided and calculate the score. Then, they should describe the actions to be taken regarding this score.

In the sixth stage, the final instrument was sent again via email for final approval by the RCP. For data analysis, tests were used to assess the psychometric properties up to the time of the NEWS 2 adaptation process, but those related to the scale's validity in the Portuguese version are still in progress.

The validity of the semantic, idiomatic, cultural, and conceptual equivalences in the answers of the members of the experts committee, in the fourth stage, was analyzed by the Content Validity Index (CVI), through the following equation: $\mathrm{CVI}=$ number of answers 3 or 4 in the Likert scale/total number of answers. This study intended to review items with a CVI lower than 0.80, as described by the experts committee, based on the available references ${ }^{(11)}$.

The reproducibility of the scale, based on the pilot study of the pre-final Portuguese version of NEWS 2, was assessed through the Kappa coefficient, using the following parameters for reliability: $0=$ Deficient; $0-0.20=$ Weak; 0.21 $0.40=$ Probable; $0.41-0.60=$ Moderate; $0.61-0.80=$ Substan tial; and $0.81-1.00=$ Perfect/Almost perfect ${ }^{(12)}$. The analysis of the scale's internal consistency was assessed through Cronbach's Alpha, with the following reference values: $<0.21=$ Limited; $0.21-0.40=$ Reasonable; $0.41-0.60=$ Mod erate; $0.61-0.80=$ Substantial; $>0.80=$ Almost perfect ${ }^{(13)}$.

The ethical aspects related to the study were followed in all the stages of the process. The project was evaluated by the Research Ethics Committees of two Brazilian universities, one federal and one private, and was approved under CAAE numbers 69013917.1.0000.5345 and 69013917.1.3001.5336, respectively. All the participants in the equivalence analysis and pilot test stages were instructed and clarified about the objectives of the study, and signed the Free and Informed Consent Form (FICF). The study was carried out after approval and clearance of the Royal College of Physicians, with clarifications during the stages and review of the final version, according to the proposed methodology. 


\section{RESULTS}

As recommended by Beaton et al. ${ }^{(10)}$, the results of the cross-cultural adaptation of NEWS 2 to Brazilian Portuguese are presented taking into account the six stages previously described.

Chart 1 presents a synthesis of the four initial stages of the process to transculturally adapt NEWS 2 to Brazilian Portuguese. The final version used (after analysis of equivalences) and the justification for maintaining them are also presented, even if they differ from the original version. These initial stages took place as proposed by the authors of the method, with no particularities ${ }^{(10)}$.

Still in stage IV, the semantic, idiomatic, cultural, and conceptual equivalences were evaluated by the Experts Committee, composed of 83 invitations sent (of which 37 were returned), but with the effective participation of 18 professionals (11 nurses and 7 physicians), from 11 Brazilian cities, including nine states, namely: Rio Grande do Sul, Santa Catarina, Paraná, Goiás, Rio de Janeiro, São Paulo, Maranhão, Piauí, and Ceará. Of these, seven professionals had some specialization, five had masters and six had doctorates, and were involved in teaching, assistance, and management.

The professionals took a mean of 19 days to return the evaluated instrument and, of these, two had already used the original NEWS, through a literal translation made in their institutions of origin, in the assessment of patients.

In total, 62 items were cross-culturally adapted and assessed by the Committee for equivalences. The mean Content Validity Indexes, by equivalence, are shown in Table 1. The instruments obtained a mean $\mathrm{CVI}$ of 0.98 , being considered valid.

The finished instruments were sent to a design team, so that the artwork was in accordance with the RCP's request to maintain the original model, sent to the RCP for authorization and, afterwards, the pilot test of the final version was carried out.

The pilot test of the final version of the items was carried out in stage $V$ with the participation of 35 nurses, $86.5 \%$ female $(n=30)$, with a mean age of 31.97 years old (standard deviation of \pm 5.85 ), mean time since graduation of five years, and $48.6 \%$ with Lato Sensu post-graduate education. Five participants had an MS or a PhD. Regarding their place of work, $60 \%$ worked in the Emergency Department, while $40 \%$ worked in Inpatient Units. The nurses applied the translated instruments assessing three case studies based on the RCP. It should be noted that this stage occurred within the work environment, after a brief explanation about the instrument, in a controlled condition and without contact among the participants.
The final version of the translated scale, the chart of operational definitions, and the observation chart are presented in Figures 1 and 2.

The Observation chart of the National Early Warning Score 2 (NEWS 2), an instrument for recording vital signs following the NEWS 2 color scheme and warning signs, was also translated and adapted for the Brazilian version and is available to the interested parties through contact with the authors of this study.

The assessment of the reliability and reproducibility of the items of the main instrument used the Kappa coefficient. The data, described through the items, are described in Table 2.

The inter-rater agreement proved to be "almost perfect", with scores ranging from 0.88 to 1.00. Regarding the internal consistency of the scale, the assessment used the Cronbachis Alpha coefficient, obtaining a total result of 0.712 . In the individual analysis of each item, the result was 0.811 if the Systolic Blood Pressure (SBP) item was deleted.

In the pilot test, with the application of the cases, the percentage of correct answers was analyzed. Case 1 presented $82.8 \%$ of correct answers; case 2, 94.28\%; and case 3, 100\%. The errors related to case 1 were linked to the "Ambient air or oxygen" item, with a Kappa value lower than the other items. The four individuals who did not obtain 100\% in the calculation of the NEWS 2 score showed a sum equal to 11 , as they did not add the "Ambient air or oxygen" item.

Regarding the conducts, based on the NEWS 2 Operational Definitions Chart - Brazilian version, case 1 had 100\% of correct answers; case 2, 94.28\%; and case 3, 94.28\%. Finally, in the last stage of the study, the process carried out and the final version of NEWS 2 were sent back to the RCP, obtaining approval and authorization for publication of the cross-culturally instrument adapted for Brazil.

\section{DISCUSSION}

The cross-cultural adaptation process of NEWS $2 \mathrm{ob}-$ served the stages proposed by the methodology employed and was successful. However, with regard to NEWS 2, this process is unprecedented, due to the 2017 change in NEWS, with few articles related to efficiency, sensitivity, and other parameters for the updated version of NEWS 2. To date, there are no publications of similar processes in other countries and languages.

Currently, in Brazil, hospitals and other health institutions use tools to predict risks or support decision making for transferring patients, intensifying care and triggering rapid response teams, for example. This practice is relatively new, mainly associated with the growth of processes aimed at patient safety and quality of care. 


\begin{tabular}{|c|c|c|c|c|c|}
\hline \multicolumn{6}{|c|}{ Instrument: The NEWS scoring system 2} \\
\hline \multicolumn{6}{|c|}{ Transcultural adaptation: NEWS 2 - Brazilian version } \\
\hline Item & $\begin{array}{c}\text { Original } \\
\text { Version (OV) }\end{array}$ & $\begin{array}{c}\text { Stage II } \\
\text { T1/T2 (T12) }\end{array}$ & $\begin{array}{l}\text { Stage III } \\
\text { Back-translation } \\
\text { (B1/B2) }\end{array}$ & $\begin{array}{l}\text { Final version After } \\
\text { Experts Committee }\end{array}$ & $\begin{array}{l}\text { Observations/Justifications sent } \\
\text { to the Royal College of Physi- } \\
\text { cians (RCP) and accepted }\end{array}$ \\
\hline 1 & Physiological parameter & Parâmetros Fisiológicos & Physiological Parameters & Parâmetros Fisiológicos & - \\
\hline 2 & Score & Pontuação & Score & Pontuação & - \\
\hline 3 & $\begin{array}{l}\text { Respiration rate } \\
\text { (per minute) }\end{array}$ & $\begin{array}{l}\text { Frequência Respiratória } \\
\text { (por minuto) }\end{array}$ & $\begin{array}{l}\text { Breathing rate } \\
\text { (per minute) }\end{array}$ & $\begin{array}{l}\text { Frequência Respiratória } \\
\text { (por minuto) }\end{array}$ & - \\
\hline 4 & SpO2 Scale 1 (\%) & SpO2 \% - Escala 1 & SpO2 \% - Scale 1 & SpO2 \% - Escala 1 & - \\
\hline 5 & SpO2 Scale $2(\%)$ & SpO2 \% - Escala 2 & SpO2 \% - Scale 2 & SpO2 \% - Escala 2 & - \\
\hline 6 & On air & Em ar ambiente & On ambient air & Em ar ambiente & - \\
\hline 7 & On oxygen & Com oxigênio & With oxygen & Com oxigênio & $\begin{array}{l}\text { In Brazil, the expression "ar ambiente" } \\
\text { (ambient air) is a synonym for the } \\
\text { expression "on air" in English. }\end{array}$ \\
\hline 8 & Air or oxygen? & $\begin{array}{l}\text { Ar ambiente } \\
\text { ou oxigênio? }\end{array}$ & Ambient air or oxygen? & $\begin{array}{l}\text { Ar ambiente } \\
\text { ou oxigênio? }\end{array}$ & - \\
\hline 9 & Oxygen & Oxigênio & Oxygen & Oxigênio & - \\
\hline 10 & Air & Ar ambiente & Ambient air & Ar ambiente & $\begin{array}{l}\text { In Brazil, the expression "ar ambiente" } \\
\text { (ambient air) is a synonym for the } \\
\text { expression "on air" in English. }\end{array}$ \\
\hline 11 & $\begin{array}{l}\text { Systolic blood } \\
\text { pressure (mmHg) }\end{array}$ & $\begin{array}{l}\text { Pressão Arterial } \\
\text { Sistólica (mmHg) }\end{array}$ & $\begin{array}{l}\text { Systolic blood } \\
\text { pressure (mmHg) }\end{array}$ & $\begin{array}{l}\text { Pressão Arterial } \\
\text { Sistólica (mmHg) }\end{array}$ & - \\
\hline
\end{tabular}

Chart 1 - Presentation of the evolution of the transcultural adaptation of NEWS 2 - Brazilian version, according to stages I, II, III, and IV. Porto Alegre/RS, 2018 


\begin{tabular}{|c|c|c|c|c|c|}
\hline \multicolumn{6}{|c|}{ Instrument: The NEWS scoring system 2} \\
\hline \multicolumn{6}{|c|}{ Transcultural adaptation: NEWS 2 - Brazilian version } \\
\hline Item & $\begin{array}{c}\text { Original } \\
\text { Version (OV) }\end{array}$ & $\begin{array}{c}\text { Stage II } \\
\text { T1/T2 (T12) }\end{array}$ & $\begin{array}{c}\text { Stage III } \\
\text { Back-translation } \\
\text { (B1/B2) }\end{array}$ & $\begin{array}{l}\text { Final version After } \\
\text { Experts Committee }\end{array}$ & $\begin{array}{l}\text { Observations/Justifications sent } \\
\text { to the Royal College of Physi- } \\
\text { cians (RCP) and accepted }\end{array}$ \\
\hline 12 & Pulse (per minute) & Pulso (por minuto) & Pulse (per minute) & Pulso (por minuto) & - \\
\hline 13 & Consciousness & Consciência & Consciousness & Consciência & - \\
\hline 14 & Alert & Alerta & Alert & Alerta & - \\
\hline 15 & AVPU & $\begin{array}{l}\text { Confusão aguda/ } \\
\text { Resposta a voz ou a } \\
\text { dor/Irresponsivo }\end{array}$ & $\begin{array}{l}\text { Acute confusion/Voice } \\
\text { or pain response/ } \\
\text { Not responsive }\end{array}$ & $\begin{array}{l}\text { Confusão aguda/ } \\
\text { Resposta a voz ou a } \\
\text { dor/ Irresponsivo }\end{array}$ & $\begin{array}{l}\text { The AVPU scale is not used in Brazil. The } \\
\text { Glasgow Coma Scale is usually used } \\
\text { to assess level of consciousness. In } \\
\text { order not to interfere with the original } \\
\text { version, it was decided to describe the } \\
\text { items in full. }\end{array}$ \\
\hline 16 & Temperature $\left({ }^{\circ} \mathrm{C}\right)$ & Temperatura $\left({ }^{\circ} \mathrm{C}\right)$ & Temperature $\left({ }^{\circ} \mathrm{C}\right)$ & Temperatura $\left({ }^{\circ} \mathrm{C}\right)$ & - \\
\hline 17 & NEW score & Pontuação NEWS & NEWS Score & Pontuação NEWS & - \\
\hline 18 & $\begin{array}{l}\text { Frequency } \\
\text { of monitoring }\end{array}$ & $\begin{array}{c}\text { Frequência } \\
\text { de monitoramento }\end{array}$ & Monitoring Frequency & $\begin{array}{c}\text { Frequência } \\
\text { de monitoramento }\end{array}$ & - \\
\hline 19 & Clinical response & Resposta clínica & Clinical Response & Resposta clínica & - \\
\hline 20 & Minimum 12 hourly & Mínimo a cada 12 horas & $\begin{array}{l}\text { Minimum at every } \\
12 \text { hours }\end{array}$ & Mínimo a cada 12 horas & $\begin{array}{c}\text { In Brazil, we do not use the expression } \\
\text { "hourly", we say "a cada hora" } \\
\text { (every hour)... }\end{array}$ \\
\hline
\end{tabular}

Chart 1 - Cont. 


\begin{tabular}{|c|c|c|c|c|c|}
\hline \multicolumn{6}{|c|}{ Instrument: The NEWS scoring system 2} \\
\hline \multicolumn{6}{|c|}{ Transcultural adaptation: NEWS 2 - Brazilian version } \\
\hline Item & $\begin{array}{c}\text { Original } \\
\text { Version (OV) }\end{array}$ & $\begin{array}{c}\text { Stage II } \\
\text { T1/T2 (T12) }\end{array}$ & $\begin{array}{c}\text { Stage III } \\
\text { Back-translation } \\
\text { (B1/B2) }\end{array}$ & $\begin{array}{l}\text { Final version After } \\
\text { Experts Committee }\end{array}$ & $\begin{array}{l}\text { Observations/Justifications sent } \\
\text { to the Royal College of Physi- } \\
\text { cians (RCP) and accepted }\end{array}$ \\
\hline 21 & $\begin{array}{l}\text { Continue routine } \\
\text { NEWS monitoring }\end{array}$ & $\begin{array}{l}\text { Continuar com o } \\
\text { monitoramento NEWS } \\
\text { de rotina. }\end{array}$ & $\begin{array}{l}\text { Continue with routine } \\
\text { NEWS monitoring }\end{array}$ & $\begin{array}{l}\text { Continuar com o } \\
\text { monitoramento NEWS } \\
\text { de rotina. }\end{array}$ & - \\
\hline 22 & Total 1-4 & Total 1-4 & Total 1-4 & Total 1-4 & - \\
\hline 23 & Minimum 4-6 hourly & Mínimo a cada 4-6 horas & $\begin{array}{c}\text { Minimum at every } \\
\text { 4-6 hours }\end{array}$ & Mínimo a cada 4-6 horas & $\begin{array}{l}\text { In Brazil, we do not use the expression } \\
\text { "hourly", we say"a cada hora" } \\
\text { (every hour)... }\end{array}$ \\
\hline 24 & $\begin{array}{l}\text { Inform registered } \\
\text { nurse, who must assess } \\
\text { the patient }\end{array}$ & $\begin{array}{l}\text { Informar o enfermeiro, } \\
\text { que ele deve avaliar } \\
\text { o paciente }\end{array}$ & $\begin{array}{l}\text { Inform the nurse that } \\
\text { he should evaluate } \\
\text { the patient. }\end{array}$ & $\begin{array}{l}\text { Informar o enfermeiro, } \\
\text { que ele deve avaliar } \\
\text { o paciente }\end{array}$ & $\begin{array}{l}\text { In Brazil, we do not have the "Registered } \\
\text { Nurse" position. We have "Nurses" with } \\
\text { higher education, who are responsible } \\
\text { for the assessment of the patient. }\end{array}$ \\
\hline 25 & $\begin{array}{l}\text { Registered nurse } \\
\text { decides whether } \\
\text { increased frequency } \\
\text { of monitoring and/ } \\
\text { or escalation of care } \\
\text { is required. }\end{array}$ & $\begin{array}{l}\text { O Enfermeiro deve } \\
\text { decidir se o aumento } \\
\text { da frequência de } \\
\text { monitoramento e/ } \\
\text { ou intensificação do } \\
\text { cuidado é necessário. }\end{array}$ & $\begin{array}{l}\text { The nurse must decide } \\
\text { whether increasing the } \\
\text { monitoring frequency } \\
\text { and/or intensifying the } \\
\text { care is required. }\end{array}$ & $\begin{array}{l}\text { O Enfermeiro deve } \\
\text { decidir se o aumento } \\
\text { da frequência de } \\
\text { monitoramento e/ } \\
\text { ou intensificação do } \\
\text { cuidado é necessário. }\end{array}$ & - \\
\hline 26 & 3 in single parameter & $\begin{array}{l}3 \text { em um } \\
\text { único parâmetro }\end{array}$ & 3 in a single parameter & $\begin{array}{l}3 \text { em um } \\
\text { único parâmetro }\end{array}$ & - \\
\hline 27 & Minimum 1 hourly & Mínimo a cada 1 hora & Minimum at every 1 hour & Mínimo a cada 1 hora & - \\
\hline
\end{tabular}

Chart 1 - Cont. 


\begin{tabular}{|c|c|c|c|c|c|}
\hline \multicolumn{6}{|c|}{ Instrument: The NEWS scoring system 2} \\
\hline \multicolumn{6}{|c|}{ Transcultural adaptation: NEWS 2 - Brazilian version } \\
\hline Item & $\begin{array}{c}\text { Original } \\
\text { Version (OV) }\end{array}$ & $\begin{array}{c}\text { Stage II } \\
\text { T1/T2 (T12) }\end{array}$ & $\begin{array}{c}\text { Stage III } \\
\text { Back-translation } \\
\text { (B1/B2) }\end{array}$ & $\begin{array}{l}\text { Final version After } \\
\text { Experts Committee }\end{array}$ & $\begin{array}{l}\text { Observations/Justifications sent } \\
\text { to the Royal College of Physi- } \\
\text { cians (RCP) and accepted }\end{array}$ \\
\hline 28 & $\begin{array}{l}\text { Registered nurse to } \\
\text { inform medical team } \\
\text { caring for the patient, } \\
\text { who will review and } \\
\text { decide whether } \\
\text { escalation of care } \\
\text { is necessary. }\end{array}$ & $\begin{array}{l}\text { O Enfermeiro deve } \\
\text { informar a equipe } \\
\text { médica que está } \\
\text { cuidando do paciente, } \\
\text { que revisará e decidirá } \\
\text { se a intensificação dos } \\
\text { cuidados é necessária. }\end{array}$ & $\begin{array}{l}\text { The nurse must inform } \\
\text { the medical team } \\
\text { which is taking care of } \\
\text { the patient, that he/ } \\
\text { she will review and } \\
\text { will decide whether } \\
\text { care intensification } \\
\text { is necessary. }\end{array}$ & $\begin{array}{l}\text { O Enfermeiro deve } \\
\text { informar a equipe } \\
\text { médica que está } \\
\text { cuidando do paciente, } \\
\text { que revisará e decidirá } \\
\text { se a intensificação dos } \\
\text { cuidados é necessária. }\end{array}$ & - \\
\hline 29 & $\begin{array}{c}\text { Total } 5 \text { or more/ Urgent } \\
\text { response threshold }\end{array}$ & $\begin{array}{l}\text { Total de } 5 \text { ou } \\
\text { mais/ Limite de } \\
\text { resposta urgente }\end{array}$ & $\begin{array}{l}\text { Total of } 5 \text { or more/ } \\
\text { Urgent response limit }\end{array}$ & $\begin{array}{l}\text { Total de } 5 \text { ou } \\
\text { mais/ Limite de } \\
\text { resposta urgente }\end{array}$ & - \\
\hline 30 & $\begin{array}{l}\text { Registered nurse to } \\
\text { immediately inform the } \\
\text { medical team caring } \\
\text { for the patient. }\end{array}$ & $\begin{array}{l}\text { O Enfermeiro deve } \\
\text { informar imediatamente } \\
\text { a equipe médica } \\
\text { que está cuidando } \\
\text { do paciente. }\end{array}$ & $\begin{array}{l}\text { The nurse must } \\
\text { immediately inform the } \\
\text { medical team that he/ } \\
\text { she is taking care of } \\
\text { the patient. }\end{array}$ & $\begin{array}{l}\text { O Enfermeiro deve } \\
\text { informar imediatamente } \\
\text { a equipe médica } \\
\text { que está cuidando } \\
\text { do paciente. }\end{array}$ & - \\
\hline 31 & $\begin{array}{l}\text { Registered nurse } \\
\text { to request urgent } \\
\text { assessment by a } \\
\text { clinician or team with } \\
\text { care competencies } \\
\text { in the care of acutely } \\
\text { ill patients. }\end{array}$ & $\begin{array}{l}\text { O Enfermeiro deve } \\
\text { solicitar avaliação } \\
\text { urgente de um médico } \\
\text { ou de uma equipe } \\
\text { com competências } \\
\text { essenciais no cuidado } \\
\text { de pacientes com uma } \\
\text { doença aguda. }\end{array}$ & $\begin{array}{c}\text { The Nurse must request } \\
\text { an urgent evaluation of } \\
\text { a doctor of a team with } \\
\text { essential abilities in the } \\
\text { care of patients with an } \\
\text { acute illness. }\end{array}$ & $\begin{array}{c}\text { O Enfermeiro deve } \\
\text { solicitar avaliação } \\
\text { urgente de um médico } \\
\text { ou de uma equipe com } \\
\text { competências essenciais } \\
\text { no cuidado de pacientes } \\
\text { com uma doença aguda. }\end{array}$ & - \\
\hline
\end{tabular}

Chart 1 - Cont. 


\begin{tabular}{|c|c|c|c|c|c|}
\hline \multicolumn{6}{|c|}{ Instrument: The NEWS scoring system 2} \\
\hline \multicolumn{6}{|c|}{ Transcultural adaptation: NEWS 2 - Brazilian version } \\
\hline Item & $\begin{array}{c}\text { Original } \\
\text { Version (OV) }\end{array}$ & $\begin{array}{c}\text { Stage II } \\
\text { T1/T2 (T12) }\end{array}$ & $\begin{array}{c}\text { Stage III } \\
\text { Back-translation } \\
\text { (B1/B2) }\end{array}$ & $\begin{array}{l}\text { Final version After } \\
\text { Experts Committee }\end{array}$ & $\begin{array}{l}\text { Observations/Justifications sent } \\
\text { to the Royal College of Physi- } \\
\text { cians (RCP) and accepted }\end{array}$ \\
\hline 32 & $\begin{array}{l}\text { Provide clinical care in } \\
\text { an environment with } \\
\text { monitoring facilities. }\end{array}$ & $\begin{array}{l}\text { Providenciar cuidado } \\
\text { clínico em um ambiente } \\
\text { com instalações } \\
\text { de monitoramento. }\end{array}$ & $\begin{array}{l}\text { Provide clinical care in } \\
\text { an environment with } \\
\text { monitoring facilities. }\end{array}$ & $\begin{array}{c}\text { Providenciar cuidado } \\
\text { clínico em um ambiente } \\
\text { com instalações } \\
\text { de monitoramento. }\end{array}$ & - \\
\hline 33 & $\begin{array}{l}\text { Total } 7 \text { or more / } \\
\text { Emergency } \\
\text { response threshold }\end{array}$ & $\begin{array}{l}\text { Total de } 7 \text { ou mais/ } \\
\text { Limite de resposta } \\
\text { de emergência }\end{array}$ & $\begin{array}{l}\text { Total of } 7 \text { or } \\
\text { more/ Emergency } \\
\text { response limit }\end{array}$ & $\begin{array}{l}\text { Total de } 7 \text { ou mais/ } \\
\text { Limite de resposta } \\
\text { de emergência }\end{array}$ & - \\
\hline 34 & $\begin{array}{l}\text { Continuous monitoring } \\
\text { of vital signs }\end{array}$ & $\begin{array}{l}\text { Monitoramento } \\
\text { contínuo dos } \\
\text { sinais vitais. }\end{array}$ & $\begin{array}{c}\text { Continuous monitoring } \\
\text { of vital signs }\end{array}$ & $\begin{array}{l}\text { Monitoramento contínuo } \\
\text { dos sinais vitais. }\end{array}$ & - \\
\hline 35 & $\begin{array}{l}\text { Registered nurse to } \\
\text { immediately inform the } \\
\text { medical team caring } \\
\text { for the patient - this } \\
\text { should be at least at } \\
\text { specialist registrar level. }\end{array}$ & $\begin{array}{l}\text { O Enfermeiro deve } \\
\text { informar imediatamente } \\
\text { a equipe médica que } \\
\text { está cuidando do } \\
\text { paciente - isso deve } \\
\text { ser feito diretamente } \\
\text { ao especialista. }\end{array}$ & $\begin{array}{l}\text { The Nurse should } \\
\text { immediately inform the } \\
\text { medical team that in } \\
\text { charge of the patient - } \\
\text { this should be provided } \\
\text { directly to the specialist. }\end{array}$ & $\begin{array}{l}\text { O Enfermeiro deve } \\
\text { informar imediatamente } \\
\text { a equipe médica que } \\
\text { está cuidando do } \\
\text { paciente - isso deve } \\
\text { ser feito diretamente } \\
\text { ao especialista. }\end{array}$ & - \\
\hline
\end{tabular}

Chart 1 - Cont. 


\begin{tabular}{|c|c|c|c|c|c|}
\hline \multicolumn{6}{|c|}{ Instrument: The NEWS scoring system 2} \\
\hline \multicolumn{6}{|c|}{ Transcultural adaptation: NEWS 2 - Brazilian version } \\
\hline Item & $\begin{array}{c}\text { Original } \\
\text { Version (OV) }\end{array}$ & $\begin{array}{c}\text { Stage II } \\
\text { T1/T2 (T12) }\end{array}$ & $\begin{array}{c}\text { Stage III } \\
\text { Back-translation } \\
\text { (B1/B2) }\end{array}$ & $\begin{array}{l}\text { Final version After } \\
\text { Experts Committee }\end{array}$ & $\begin{array}{l}\text { Observations/Justifications sent } \\
\text { to the Royal College of Physi- } \\
\text { cians (RCP) and accepted }\end{array}$ \\
\hline 36 & $\begin{array}{l}\text { Emergency assessment } \\
\text { by a team with critical } \\
\text { care competencies, } \\
\text { including } \\
\text { practitioner(s) with } \\
\text { advanced airway } \\
\text { management skills. }\end{array}$ & $\begin{array}{c}\text { Avaliação de } \\
\text { emergência por } \\
\text { uma equipe com } \\
\text { competências em } \\
\text { cuidado crítico, } \\
\text { incluindo médico(s) } \\
\text { com habilidades } \\
\text { avançadas em } \\
\text { vias aéreas. }\end{array}$ & $\begin{array}{l}\text { Emergency assessment } \\
\text { by a team with critical } \\
\text { care skills, including } \\
\text { physician(s) with } \\
\text { advanced airway skills. }\end{array}$ & $\begin{array}{l}\text { Avaliação de emergência } \\
\text { por uma equipe } \\
\text { com competências } \\
\text { em cuidado crítico, } \\
\text { incluindo médico(s) com } \\
\text { habilidades avançadas } \\
\text { em vias aéreas. }\end{array}$ & $\begin{array}{l}\text { It was decided to use the term "equipe' } \\
\text { ("team") because, in Brazil, qualified } \\
\text { nurses can use the laryngeal mask } \\
\text { device, while there is a medical team } \\
\text { with skills to manage the airways } \\
\text { with other devices (orotracheal tube, } \\
\text { for example). }\end{array}$ \\
\hline 37 & $\begin{array}{l}\text { Consider transfer of } \\
\text { care to a level } 2 \text { or } 3 \\
\text { clinical care facility, ie } \\
\text { higher-dependency } \\
\text { unit or ICU. }\end{array}$ & $\begin{array}{l}\text { Considerar a } \\
\text { transferência de cuidado } \\
\text { para uma unidade de } \\
\text { tratamento de nível } 2 \text { ou } \\
\text { 3, ou seja, uma unidade } \\
\text { intermediária ou UTI. }\end{array}$ & $\begin{array}{l}\text { Consider transferring } \\
\text { the care rendering to a } \\
\text { level } 2 \text { or } 3 \text { treatment } \\
\text { unit, in other words, an } \\
\text { intermediate unit or } \\
\text { the ICU. }\end{array}$ & $\begin{array}{l}\text { Considerar a } \\
\text { transferência de cuidado } \\
\text { para uma unidade de } \\
\text { tratamento de nível } 2 \text { ou } \\
\text { 3, ou seja, uma unidade } \\
\text { intermediária ou UTI. }\end{array}$ & $\begin{array}{l}\text { In Brazil, we do not commonly name } \\
\text { levels of care like "2 or 3", but rather } \\
\text { name them as intermediate care units } \\
\text { and intensive care units. }\end{array}$ \\
\hline 38 & $\begin{array}{l}\text { Clinical care in an } \\
\text { environment with } \\
\text { monitoring facilities. }\end{array}$ & $\begin{array}{l}\text { Cuidado clínico } \\
\text { em um ambiente } \\
\text { com instalações } \\
\text { de monitoramento. }\end{array}$ & $\begin{array}{l}\text { Clinical care in an } \\
\text { environment with } \\
\text { monitoring facilities. }\end{array}$ & $\begin{array}{l}\text { Cuidado clínico } \\
\text { em um ambiente } \\
\text { com instalações } \\
\text { de monitoramento. }\end{array}$ & - \\
\hline
\end{tabular}

Chart 1 - Cont.

Source: The authors, 2018. 
Table 1 - Description of the Content Validity Index resulting from the analysis of semantic, idiomatic, cultural, and conceptual equivalences by the adjudicators of the experts committee for NEWS 2. Porto Alegre/RS, 2018

\begin{tabular}{lccc} 
Equivalences & $\begin{array}{c}\text { CVI } \\
\text { NEWS 2- Brazilian } \\
\text { version }\end{array}$ & $\begin{array}{c}\text { CVI } \\
\text { Chart of operation- } \\
\text { al definitions for } \\
\text { NEWS 2 - Brazilian } \\
\text { version }\end{array}$ & Mean CVI \\
\hline Semantic & 0.99 & 0.97 & 0.98 \\
\hline Idiomatic & 0.99 & 0.97 & 0.98 \\
\hline Cultural & 0.99 & 0.98 & 0.98 \\
\hline Conceptual & 0.99 & 0.98 & 0.98 \\
\hline Mean & 0.99 & 0.97 & 0.98
\end{tabular}

Source: The authors, 2018.

* CVI: Content Validity Index.

National Early Warning Score 2 (NEWS 2) - versáo brasileira

\begin{tabular}{|c|c|c|c|c|c|c|c|}
\hline \multirow{2}{*}{$\begin{array}{l}\text { Parâmetros } \\
\text { Fisiológicos }\end{array}$} & \multicolumn{7}{|c|}{ Pontuaçāo } \\
\hline & 3 & 2 & 1 & $\mathbf{0}$ & 1 & 2 & 3 \\
\hline $\begin{array}{l}\text { Frequência respiratória } \\
\text { (por minuto) }\end{array}$ & $\leq 8$ & & 9.11 & $12-20$ & & $21-24$ & $\geq 25$ \\
\hline Sp02 \% - Escala 1 & $\leq 91$ & $92-93$ & $94-95$ & $\geq 96$ & & & \\
\hline Sp02 \% - Escala 2 & $\leq 83$ & $84-85$ & $86-87$ & $\begin{array}{c}88-92 \\
\geq 93 \mathrm{~cm} \text { ar } \\
\text { ambiente }\end{array}$ & $\begin{array}{l}93-94 \text { com } \\
\text { oxigênio }\end{array}$ & $\begin{array}{l}95-96 \text { com } \\
\text { oxigênio }\end{array}$ & $\begin{array}{l}\geq 97 \text { com } \\
\text { oxigênio }\end{array}$ \\
\hline $\begin{array}{l}\text { Ar ambiente ou } \\
\text { oxigênio? }\end{array}$ & & Oxigênio & & Ar Ambiente & & & \\
\hline $\begin{array}{l}\text { Pressáo arterial } \\
\text { sistólica(mmHg) }\end{array}$ & $\leq 90$ & $91-100$ & $101-110$ & $111-219$ & & & $\geq 220$ \\
\hline Pulso (por minuto) & $\leq 40$ & & $41-50$ & $51-90$ & $91-110$ & $111-130$ & $\geq 131$ \\
\hline Consciência & & & & Alerta & & & $\begin{array}{l}\text { Confusāo } \\
\text { aguda } \\
\text { Resposta a } \\
\text { voz ou dor } \\
\text { Irresposivo }\end{array}$ \\
\hline Temperatura $\left({ }^{\circ} \mathrm{C}\right)$ & $\leq 35.0$ & & $35.1-36.0$ & $36.1-38.0$ & $38.1-39.0$ & $\geq 39.1$ & \\
\hline
\end{tabular}

National Early Warning Score 2 (NEWS 2) đa Royal College Of Physicians 2017. Adaptaçâo transcultural para português. Brasil, 2018.

Figure 1 - National Early Warning Score 2 - NEWS 2 - Brazilian version. Porto Alegre/RS, 2018 Source: The authors, 2018. 
Table 2 - Assessment of the inter-rater agreement regarding the items of NEWS 2 - Brazilian version. Porto Alegre/RS, 2018. $\mathrm{n}=35$ participants

\begin{tabular}{lccc}
\hline Variables & Kappa & Z-Statistic & p-value \\
Respiratory Rate & 1.000 & 10.247 & $<0.001$ \\
\hline Oxygen Saturation $\left(\mathrm{SPO}_{2}\right)$ & 0.986 & 14.286 & $<0.001$ \\
\hline Ambient air or oxygen & 0.889 & 9.165 & $<0.001$ \\
\hline Systolic Arterial Pressure & 0.979 & 10.031 & $<0.001$ \\
\hline Pulse & 1.000 & 10.247 & $<0.001$ \\
\hline Conscience & 0.978 & 10.028 & $<0.001$ \\
\hline Temperature & 1.000 & 10.359 & $<0.001$ \\
\hline
\end{tabular}

Source: The authors, 2018.

\section{Descrição da resposta clínica dos desencadeadores NEWS 2 - versão brasileira}

\begin{tabular}{|c|c|c|}
\hline Pontuação NEWS 2 & Frequência de Monitoramento & Resposta Clínica \\
\hline $\mathbf{0}$ & Mínimo a cada 12 horas & - Continuar com monitoramento NEWS 2 de rotina \\
\hline Total 1-4 & Mínimo a cada 4-6 horas & $\begin{array}{l}\text { - Informar o enfermeiro, que ele deve avaliar o paciente* } \\
\text { o Enfermeiro deve decidir se o aumento da frequência } \\
\text { de monitoramento elou intensificação do cuidado é } \\
\text { necessário }\end{array}$ \\
\hline $\begin{array}{l}3 \text { em um único } \\
\text { parâmetro }\end{array}$ & Minimo a cada 1 hora & $\begin{array}{l}\text { - O Enfermeiro deve informar a equipe médica que está } \\
\text { cuidando do paciente, que revisará e decidirá se a } \\
\text { intensificação dos cuidados é necessária }\end{array}$ \\
\hline $\begin{array}{l}\text { Total de } 5 \text { ou mais } \\
\text { Limite de resposta } \\
\text { urgente }\end{array}$ & Mínimo a cada 1 hora & $\begin{array}{l}\text { - O Enfermeiro deve informar imediatamente a } \\
\text { equipe médica que está cuidando do paciente } \\
\text { - Enfermeiro deve solicitar avaliação urgente de um } \\
\text { médico ou de uma equipe com competências } \\
\text { essenciais no cuidado de pacientes com uma doença } \\
\text { aguda } \\
\text { - Providenciar cuidado clínico em um ambiente com } \\
\text { instalações de monitoramento }\end{array}$ \\
\hline $\begin{array}{l}\text { Total de } 7 \text { ou mais } \\
\text { Limite de resposta de } \\
\text { emergência }\end{array}$ & $\begin{array}{l}\text { Monitoramento contínuo dos } \\
\text { sinais vitais }\end{array}$ & $\begin{array}{l}\text { - O Enfermeiro deve informar imediatamente a equipe } \\
\text { médica que está cuidando do paciente - isso deve ser } \\
\text { feito diretamente ao especialista } \\
\text { - Avaliação de emergência por uma equipe com } \\
\text { competências em cuidado crítico, incluindo médico(s) } \\
\text { com habilidades avançadas em vias aéreas } \\
\text { - Considerar a transferência de cuidado para uma } \\
\text { unidade de tratamento de nível } 2 \text { ou } 3 \text {, ou seja, } \\
\text { uma unidade intermediária ou UTI. } \\
\text { - Cuidado clínico em um ambiente com instalações de } \\
\text { monitoramento }\end{array}$ \\
\hline
\end{tabular}

National Early Warning Score 2 (NEWS 2) @Royal College Of Physicians 2017. Adaptạ̧ão transcultural para português. Brasil, 2018.

*Se avaliado pelo enfermeiro, considerar a opção seguinte.

Figure 2 - Description table of the clinical response of the NEWS 2 - Brazilian version triggers. Porto Alegre/RS, 2018. Source: The authors, 2018. 
One of the most used scores is the Modified Early Warning Scoring (MEWS) which, in its validation for identifying severity in patients admitted to the ICU, in Brazil, presented positive results ${ }^{(14)}$. However, the international literature ${ }^{(15)}$ still shows that this score has inferior results when compared to NEWS, even in its previous version, justifying the choice of this tool for the process of cross-cultural adaptation for use in Brazil. In this sense, it is important to mention that the process of cross-cultural adaptation involves very important stages to ensure that the final product is equivalent to the original version. The standardization of an EWS appears to be an important alternative for improving communication among health professionals and improving case identification ${ }^{(16)}$.

Another score recently adapted to Brazilian Portuguese is the Brighton Paediatric Early Warning Score (BPEWS) $)^{(17)}$. The methodological process of this study followed the same references used in the adaptation study of NEWS 2 and availed, as a product, a scale of easy access and handling, collaborating for the teamss performance and expanding the academic scope for validation studies related to this scale ${ }^{(17)}$.

The stage of the Experts Committee, carried out at the national level, allowed for the participation of several regions of the country in the analysis of the instruments, expanding its scope. Regarding the reliability resulting from the pilot test, conducted in the penultimate stage of the cross-cultural adaptation process, the results can be considered very satisfactory. The items proved to be easy to understand, with few errors related to the application of the scale. The sample invited to participate in the study uses MEWS in their care practice, which may have favored the understanding and applicability of the new translated instrument.

In Sweden, the cross-cultural adaptation study of NEWS, first version, showed that changes in consciousness and oxygen saturation represent a $77 \%$ and $27 \%$ increase in the risk of admission to the ICU, respectively, justifying the importance of these items in the instrument ${ }^{(18)}$. In the adaptation of NEWS 2 to Brazil, it became evident that these items are also important for the internal consistency of the scale, since the only item that could be removed would be"systolic blood pressure", causing an increase from 0.712 to 0.811 in the Cronbach's Alpha coefficient.

In this study, the "Consciousness" item required adaptations, since the AVPU scale, indicated in the original version, is not used in the Brazilian care practice. The item was extremely discussed in the small committee, regarding possible confusions due to the consolidated use of the Glasgow Coma Scale. However, the decision to keep the items suggested in NEWS 2 in its original version, but in a descriptive way and not in acronyms, proved to be a correct alternative since the analysis of equivalences obtained CVI results equal to 1.00, that is, characterized as "perfect". Also in the pilot application test of the NEWS-Brazilian version, an excellent success rate was obtained among the participants (Kappa $=0.978$ ). These results may indicate ease of applicability and understanding of the item.

Early warning scores are tools that stand out for their influence on clinical results, impact and uniformity of communication, and the possibility of automating some processes $^{(19)}$. However, they do not exclude the need for clinical assessment by those who apply them, thus serving as a guide for decision making and not excluding what can be called the "expertise" of the team that assists the patient ${ }^{(19)}$.

The introduction of the instrument in care practices, aiming at patient safety and serving as a basis for activating Rapid Response Teams or similar teams, requires training of the entire team that provides direct or indirect care to the patient. One study demonstrated a NEWS (old version) calculation error rate of $18.9 \%$ in a London hospital, where patients hospitalized during the weekend were more likely to receive an inadequate response when compared to those hospitalized on weekdays $(p<0.0001)^{(20)}$. The study also demonstrated that an expressive number of erroneous score calculations have direct implications in the actions taken, weakening the patient safety process ${ }^{(20)}$.

A number of studies have demonstrated the good performance of NEWS and NEWS 2 in identifying patients with sepsis, a global health problem. The inclusion of the "Acute confusion" item in the assessment of the patientrs level of consciousness contributed to better discriminate this population, favoring the process of early identification, intervention in a timely manner, and impact on unfavorable outcomes ${ }^{(6,9,16)}$.

It is necessary that new technologies, regardless of their nature, be gradually adapted to the care processes, ensuring effective empowerment of the individuals who will operate them, success in the implementation, and change of paradigms in a satisfactory way.

\section{CONCLUSION}

The study cross-culturally adapted the National Early Warning Score 2 and its support instruments to Brazilian Portuguese, through a careful methodological process whose stages are recognized worldwide. The evaluation of the semantic, idiomatic, cultural, and conceptual equivalences of each item showed an adaptation with a high content validity index, with satisfactory results and almost perfect reproducibility. The final version, approved by the RCP, allows for access and use of an instrument to identify clinical deterioration in adult patients, contributing to the quality of health care and, as a consequence, to patient safety. In 
Table 2 - Assessment of the inter-rater agreement regarding the items of NEWS 2 - Brazilian version. Porto Alegre/RS, 2018. $\mathrm{n}=35$ participants

\begin{tabular}{lccc}
\hline Variables & Kappa & Z-Statistic & p-value \\
Respiratory Rate & 1.000 & 10.247 & $<0.001$ \\
\hline Oxygen Saturation $\left(\mathrm{SPO}_{2}\right)$ & 0.986 & 14.286 & $<0.001$ \\
\hline Ambient air or oxygen & 0.889 & 9.165 & $<0.001$ \\
\hline Systolic Arterial Pressure & 0.979 & 10.031 & $<0.001$ \\
\hline Pulse & 1.000 & 10.247 & $<0.001$ \\
\hline Conscience & 0.978 & 10.028 & $<0.001$ \\
\hline Temperature & 1.000 & 10.359 & $<0.001$ \\
\hline
\end{tabular}

Source: The authors, 2018

addition to the application in the health care, this tool can be used in teaching, research, and management.

Time is signaled as one of the limitations of the study, since the update from NEWS to NEWS 2 occurred in December 2017, when the adaptation process of NEWS (original version of 2012) was almost finished. However, when the RCP communicated the researchers about the change and provided the new version, the process was immediately started, enabling the use of the updated version.

Another limitation of the study was the low adherence of professionals to make up the experts committee. However, the process is considered extremely valid and relevant, as it allowed for the adaptation with analysis of professionals from several states in Brazil and not only from the southern region, where the study was conducted.

Attention is drawn to the analysis of equivalences by professionals from nine Brazilian states, highly trained in clinical evaluation and high complexity cases, being able to provide greater representativeness not only in cultural terms, but in the applicability of NEWS 2 in Brazil.

The study to validate the instrument and define cutoff points for predicting clinical deterioration of NEWS 2 - Brazilian version (NEWS 2-B) is in progress, aiming to consolidate the results presented in this article. It is hoped that NEWS 2 , in its Brazilian version, and its applicability instruments can be incorporated into the care routine, promoting attention to a safer health process, ensuring identification and intervention in a timely manner, positively impacting on the reduction of unscheduled transfers to intensive care units, unexpected deaths, and cardiac arrest, among others.

\section{REFERENCES}

1. Morgan RJM, Williams F, Wright MM. An Early Warning Scoring System for detecting developing critical illness [Abstract]. Clin Intensive Care. 1997;8(2):100.

2. Gerry S, Birks J, Bonnici T, Watkinson PJ, Kirtley S, Collins GS. Early Warning scores for detecting deterioration in adult hospital patients: a systematic review protocol. BMJ Open. 2017;7(12):e019268. doi: https://doi.org/10.1136/ bmjopen-2017-019268

3. McGaughey J, O'Halloran P, Porter S, Blackwood B. Early Warning Systems and rapid response to the deteriorating patient in hospital: a systematic realist review. Adv Nurs. 2017;73(1):2877-91. doi: https://doi.org/10.1111/jan.13398

4. Royal College of Physicians (UK). National Early Warning Score (NEWS): Standardising the assessment of acute-illness severity in the NHS. London; 2012 [cited 2019 Jan 02]. Available from: https://www.rcplondon.ac.uk/ projects/outputs/national-early-warning-score-news-2

5. National Early Warning Score (NEWS) 2: Standardising the assessment of acute-illness severity in the NHS. Royal College of Physicians; 2017 [cited 2019 Jan 02]. Available from: https://www.rcplondon.ac.uk/projects/outputs/ national-early-warning-score-news-2

6. Pirneskoski J, Kuisma M, Olkkola KT, Nurmi J. Prehospital National Early Warning Score predicts early mortality. Acta Anaesthesiol Scand. 2019;63(1):676-83. doi: https://doi.org/10.1111/aas.13310

7. Zaidi H, Bader-El-Den M, McNicholas J. Using the National Early Warning Score (NEWS/NEWS 2) in different Intensive Care Units (ICUS) to predict the discharge location of patients. BMC Public Health. 2019;19:1231. doi: https:// doi.org//10.1186/s12889-019-7541-3

8. Silcock DJ, Corfield AR, Gowens PA, Rooney KD. Validation of the National Early Warning Score in the prehospital setting. Resuscitation. 2015;89:31-5. doi: https://doi.org/10.1016/j.resuscitation.2014.12.029 
9. Keep JW, Messmer AS, Sladden R, Burrell N, Pinate R, Tunnicliff $M$, et al. National early warning score at Emergency Department triage may allow earlier identification of patients with severe sepsis and septic shock: a retrospective observational study. Emerg Med J. 2016;33(1):37-41. doi: https://doi. org/10.1136/emermed-2014-204465

10. Beaton DE, Bombardier C, Guillemin F, Ferraz MB. Recommendations for the cross-cultural adaptation of the DASH \& QuickDASH Outcome Measures. Toronto: Institute for Work \& Health; 2007 [cited 2019 Jan 05]; Available from: $\quad$ http://dash.iwh.on.ca/sites/dash/files/downloads/cross_cultural_ adaptation_2007.pdf

11. Alexandre NMC, Coluci MZO. Validade de conteúdo nos processos de construção e adaptação de instrumentos de medidas. Ciênc Saúde Coletiva. 2011;16(7):3061-8 doi: https://doi.org/10.1590/S1413-81232011000800006

12. Siegel S, Castellan NJ, Carmona SIC, Damacena C, Silva D, Accorsi A. Estatística não-paramétrica para ciências do comportamento. Porto Alegre: Artmed; 2006.

13. Landis JR, Koch GG. The measurement of observer agreement for categorical data. Biometrics. 1977 [cited 2018 Dec 05];33(1):159-74. Available from: http://www.jstor.org/stable/2529310

14. TavaresRC,VieiraAS,UchoaLV,Peixoto JúniorAA,MenesesFA.Validation ofanearly warning score in pre-intensive care unit. Rev Bras Ter Intensiva. 2008;20(2):1247. doi: https://doi.org/10.1590/S0103-507X2008000200002
15. Jarvis SW, Kovacs C, Briggs J, Meredith P, Schmidt PE, Featherstone PI. Are observation selection methods important when comparing early warning score performance? Resuscitation. 2015;90:1-6. doi: https://doi.org/10.1016/j. resuscitation.2015.01.033

16. Inada-Kim M, Nsutebu E. NEWS 2: an opportunity to standardise the management of deterioration and sepsis. BMJ. 2018;360:k1260. doi: https:// doi.org/10.1136/bmj.k1260

17. Miranda JOF, CamargoCL,Sobrinho CLN, PortelaDS, Monaghan A, Freitas KS, etal. Tradução e adaptação de um escore pediátrico de alerta precoce. Rev Bras Enferm. 2016;69(5):888-96. doi: https://doi.org/10.1590/0034-7167-2015-0096

18. Spångfors M, Arvidsson L, Karlsson V, Samuelson K. The National Early Warning Score: translation, testing and prediction in a Swedish setting. Intensive Crit Care Nurs. 2016;37:62-7. doi: https://doi.org/10.1016/j.iccn.2016.05.007

19. Downey CL, Tahir W, Randell R, Brown JM, Jayne DG. Strengths and limitations of early warning scores: a systematic review and narrative synthesis. Int J Nurs Stud. 2017;76:106-19. doi: https://doi.org/10.1016/j.jpnurstu.2017.09.003

20. Kolic I, Crane S, McCartney S, Perkins Z, Taylor A. Factors affecting response to National Early Warning Score (NEWS). Resuscitation. 2015;90:85-90. doi: https://doi.org/10.1016/j.resuscitation.2015.02.009

\section{- Corresponding author:}

Ana Paula Amestoy de Oliveira

E-mail: anapamestoy@gmail.com

\section{Editor-in-chief:}

Maria da Graça Oliveira Crossetti 